Japan. J. Med. Sci. Biol., 34, 81-94, 1981

\title{
SUPPRESSION OF DELAYED HYPERSENSITIVITY BY MEASLES VIRUS INFECTION IN GUINEA PIGS
}

\author{
Kazuya YAMANOUCHI, Hiroaki OHTA*, Tetsuro KATAOKA**, \\ Fumio KOBUNE***, Yasuhiro YOSHIKAWA and Tohru TOKUNAGA** \\ Laboratory Animal Research Center, Institute of Medical Science, University \\ of Tokyo, Shirokanedai, Minato-ku, Tokyo 108, *Tochigi Laboratory, \\ Bio-Pharmaceuticals, Inc., Tochigi, **Department of Tuberculosis \\ and ***Department of Measles Virus, National Institute \\ of Health, Kamiosaki, Shinagawa-ku, Tokyo 141
}

(Received, December 24, 1980. Accepted, February 5, 1981)

\begin{abstract}
SUMMARY: A guinea pig model of mild measles virus infection was established by the intranasal inoculation with Toyoshima strain. The infection was confirmed by the development of both humoral and cell-mediated immunities to measles virus as well as by the demonstration of transient virus growth in the lymphoid tissues. The virus infection caused a transient suppression of delayed hypersensitivity to purified protein derivative (PPD) at both the induction and expression phases, whereas Jones-Mote-type hypersensitivity to ovalbumin developed in a normal fashion. In the virus-infected animals, the suppressed response to the skin reacting factor was observed as well, however in vitro responsiveness of lymphocytes to PPD was not suppressed. On the other hand, transient enhancement of skin reactivity to phytohemagglutinin by virus infection was noticed. These results may indicate subtle alterations of immune functions in guinea pigs during measles virus infection.
\end{abstract}

\section{INTRODUCTION}

Measles virus infection involves the lymphoid tissues as a major target for virus growth and is suspected to exhibit a variety of effects on host's immune functions. The transient unresponsiveness of measles patients to the tuberculin skin test, so-called tuberculin anergy, was first pointed out by von Pirquet (1908). Thereafter, numbers of studies have confirmed measles virus-induced immunosuppression by the demonstrations of skin reactivities to various antigens including tuberculin, candida, vaccinia virus, diphtheria toxoid, poison ivy, and 2,4dinitrochlorobenzene during natural measles infection and after vaccination with live measles vaccine (Blumhardt, Pappano, Jr. and Moyer, 1968; Brody, Overfield and Hammes, 1964; Coovadia et al., 1978; Fireman, Friday and Kumate, 1969; Mellman and Wetton, 1963; Munyer et al., 1975; Zweiman et al.,

\footnotetext{
山内一也・吉川泰弘 (東京大学医科学研究所 港区白金台 4-6-1)

大田博昭（バイオ製薬 杤木ラボ）

片岡哲朗・徳永 徹（国立予防衛生研究所 結核部）

小船富美夫（国立予防衛生研究所 麻疹ウイルス部）
} 
1971). Marked decrease in the number of peripheral blood lymphocytes including $\mathrm{T}, \mathrm{B}$, and null cells occurs during natural measles (Wesley, Coovadia and Henderson, 1978), as well.

The significance of measles virus-induced immunosuppression is not fully understood. Aggravation of chronic diseases such as tuberculosis was observed during measles (Bech, 1962), while improvement of steroid-sensitive nephrosis was also noticed (Blumberg and Cassady, 1947). Recently, the immunosuppressive capacity of measles virus has been paid special attention for the virus-induced disturbance of immunoregulatory system of the host, which might have some relevance to the pathogenesis of chronic and autoimmune diseases of unknown etiology (Morgan and Rapp, 1977; Yamanouchi, 1980).

Mechanisms of measles virus-induced immunosuppression have been studied exclusively on clinical materials of natural human measles except for one murine model in which the suppression in helper $\mathrm{T}$-cell activity by a hamster brainadapted measles virus was demonstrated (McFarland, 1974). Since the guinea pig is the most popular laboratory animal for the study of delayed hypersensitivity, we attempted to develop an experimental model for measles virusinduced suppression of delayed hypersensitivity in this animal. The present paper describes the susceptibility of the guinea pig to measles virus and the phenomenon of immunosuppression by measles virus.

\section{Materials ANd Methods}

Measles virus: Three laboratory strains (TYCSA, Toyoshima, and Edmonston), two vaccine strains [Schwarz and Leningrad-16; the former being adapted in chick embryo cells (Schwarz, 1964) and the latter in guinea pig kidney cells (Smorodintsev et al., 1965)], and an isolate from a patient with subacute sclerosing panencephalitis (SSPE) (Halle strain) were used as inoculums for guinea pigs. All of the strains were grown in Vero cells, and their infectivities were titrated by the plaque method in Vero cells in multiwell plates (Falcon 3008). For migration-inhibition and skin tests, Toyoshima strain was grown in Vero cells in Eagle's minimum essential medium (MEM) supplemented with $5 \%$ calf serum, inactivated by irradiation with ultraviolet light for 3-5 min, and used as antigen. As a control antigen, uninfected Vero cell culture fluid was used.

Guinea pig: Outbred Hartley strain guinea pigs were purchased from a commercial breeder. Unless specified, animals weighing about $300 \mathrm{~g}$ of body weight were used throughout the experiments.

Antibody titrations: Procedures for hemagglutination-inhibition (HI) antibody titration and the virus neutralization test were previously described in detail (Yamanouchi et al., 1969; Sato et al., 1978). In brief, the sera were treated with kaolin and red blood cells of African green monkeys to remove nonspecific inhibitors. Reciprocals of the serum dilutions that inhibited 4 units of measles virus hemagglutinin were expressed as HI antibody titers. Virus 
neutralization tests were carried out in Vero cell cultures in multiwell plates, and reciprocals of the serum dilutions that reduced plaque numbers to $50 \%$ were expressed as neutralizing antibody titers.

Immunofluorescent technique: The spleen and mesenteric lymph nodes were collected 4 and 7 days post inoculation (pi) with virus. Frozen sections were prepared with a cryostat, fixed in acetone at $-20 \mathrm{C}$ for $10 \mathrm{~min}$, and stained by an indirect method using measles-immune monkey serum as the first antibody and rabbit anti-human IgG serum conjugated with fluorescein isothiocyanate as the second one.

Immunization of guinea pigs with tubercle bacilli or ovalbumin: The animals were immunized by intramuscular inoculations with $0.5 \mathrm{ml}$ of liquid paraffin containing dry weight of $0.5 \mathrm{mg} / \mathrm{ml}$ of heat inactivated Mycobacterium tuberculosis Aoyama B strain, or subcutaneously with $50 \mu \mathrm{g}$ of ovalbumin (OVA; Difco Lab.).

Virus infection of guinea pigs: Virus inoculation was made by either the ip route with $0.5 \mathrm{ml}$ of virus or by the intranasal one with $0.01-0.1 \mathrm{ml}$ of virus.

Skin test: The animals were inoculated intradermally on the back with $0.1 \mathrm{ml}$ of undiluted measles virus antigen as well as control antigen, purified protein derivative (PPD; NIH, Tokyo) (0.05-0.5 $\mu \mathrm{g})$, OVA (1-10 $\mu \mathrm{g})$, or phytohemagglutinin (PHA-P; Difco Lab., 1-20 $\mu \mathrm{g}$ ). Six and $24 \mathrm{hr}$ later, the animals infected or uninfected were randomized and examined for erythema and induration of the skin.

Migration-inhibition test: Peritoneal exudate cells were collected from guinea pigs 4 days after ip injection of $10 \mathrm{ml}$ of liquid paraffin. After repeated washings in Hanks' medium, the cells were packed in capillary tubes, and the tubes were placed in migration plates containing Eagle's MEM with $20 \%$ guinea pig serum. The area of migration in the presence of virus antigen or that of control was measured by light microscopy after incubation for $24 \mathrm{hr}$ at $37 \mathrm{C}$ in $5 \% \mathrm{CO}_{2}$-air mixture.

Proliferative response of spleen cells to PPD: The spleen cells were suspended in Eagle's MEM supplemented with $20 \%$ fetal bovine serum at a concentration of $5-8 \times 10^{5}$ cells $/ 0.1 \mathrm{ml}$. A $0.1-\mathrm{ml}$ portion of the cell suspension was put into each well of microtest plates (Coster No. 3506, Cambridge, MA), and $0.1 \mathrm{ml}$ of PPD $(10,25$, or $50 \mu \mathrm{g} / 0.1 \mathrm{ml})$ was added. The spleen cell cultures were incubated at $37 \mathrm{C}$ in $5 \% \mathrm{CO}_{2}$-air mixture for 2 days, and $1 \mu \mathrm{Ci}$ of ${ }^{3} \mathrm{H}$ thymidine (Amersham Corp.; specific activity $24 \mathrm{Ci} / \mathrm{mM}$ ) was added to the cultures. After further incubation overnight, the cells were collected on a multiple cell harvester (Labo Science, Tokyo), and the incorporation of isotope was counted in a liquid scintillation counter. Stimulation index was obtained by dividing the isotope counts in the PPD-stimulated cultures by those in the unstimulated control cultures.

Skin-reacting factor $(S R F)$ : The animals previously immunized with tubercle bacilli were challenged by iv inoculation with living BCG to induce splenomegaly. The spleen cells collected 10 days later were suspended in RPMI 
1640 medium containing $50 \mu \mathrm{g}$ of $\mathrm{PPD} / \mathrm{ml}$ at a concentration of $5 \times 10^{6}$ cells $/ \mathrm{ml}$. After incubation at $37 \mathrm{C}$ in $5 \% \quad \mathrm{CO}_{2}$-air mixture for $24 \mathrm{hr}$, the culture fluid was collected and used as an SRF preparation (Watanuki, Yoshida and Hashimoto, 1969). Controls were prepared by a similar procedure without adding PPD to the cultures. One-tenth milliliter of each of two dilutions (undiluted and 1:3) was intradermally inoculated on the back of guinea pigs and skin reactions were read $6.5 \mathrm{hr}$ later.

\section{RESUlts}

\section{Susceptibility of Guinea Pigs to Measles Virus}

Six groups of guinea pigs, each consisting of six to eight animals, were inoculated intraperitoneally with six strains of measles virus. Four and 7 days pi, two to three animals were sacrificed and their spleens and mesenteric lymph nodes were examined by immunofluorescent staining. The rest of animals were bled 2 and 4 weeks pi. No clinical signs were observed in any of the animals. As summarized in Table $I$, none of the animals showed evidence of virus growth of any virus strain in the lymphoid tissues. Development of HI antibody was observed for Toyoshima, Schwarz, Leningrad-16, and Halle strains. Toyoshima strain showed the highest antibody response, whereas TYCSA and Edmonston strains failed to induce antibody response.

TABLE I

Susceptibility of guinea pigs ${ }^{a)}$ to intraperitoneal inoculations with various strains of measles virus

\begin{tabular}{|c|c|c|c|c|c|c|}
\hline \multirow{2}{*}{ Virus strain } & \multirow{2}{*}{$\underset{\text { size }^{b)}}{\text { Inoculum }}$} & \multicolumn{2}{|c|}{$\begin{array}{c}\text { Virus antigen in lymphoid } \\
\text { tissues }^{c)} \text { days pi }\end{array}$} & \multicolumn{3}{|c|}{ Antibody response wk pi } \\
\hline & & 4 & 7 & 1 & 2 & 4 \\
\hline TYCSA & $2.4 \times 10^{5}$ & $0 / 2^{d)}$ & $0 / 2$ & $0 / 2^{e)}$ & $0 / 2$ & $0 / 2$ \\
\hline Toyoshima & $3.1 \times 10^{5}$ & $0 / 2$ & $0 / 2$ & $\begin{array}{l}1 / 2 \\
(8)\end{array}$ & $\begin{array}{c}4 / 4 \\
(8,16,16,64)\end{array}$ & $\begin{array}{l}4 / 4 \\
(8,64,64,128)\end{array}$ \\
\hline Edmonston & $4.2 \times 10^{5}$ & $0 / 3$ & $0 / 3$ & $0 / 3$ & $0 / 2$ & $0 / 2$ \\
\hline Schwarz & $3.2 \times 10^{5}$ & $0 / 2$ & $0 / 2$ & $0 / 2$ & $\begin{array}{l}1 / 2 \\
(8)\end{array}$ & $\begin{array}{l}1 / 2 \\
(32)\end{array}$ \\
\hline Leningrad-16 & $1.6 \times 10^{6}$ & $0 / 2$ & $0 / 2$ & $0 / 2$ & $\begin{array}{l}1 / 2 \\
(32)\end{array}$ & $\mathrm{NT} f)$ \\
\hline Halle & $9.0 \times 10^{2}$ & $0 / 2$ & $0 / 2$ & $0 / 2$ & $\begin{array}{l}1 / 2 \\
(8)\end{array}$ & $\begin{array}{l}1 / 2 \\
(8)\end{array}$ \\
\hline
\end{tabular}

\footnotetext{
a) Hartley strain with body weight of over $250 \mathrm{~g}$.

b) PFU/animal.

c) The spleen and mesenteric lymph nodes were examined by immunofluorescent technique.

d) Antigen-positive animals/Number tested.

e) HI antibody-positive animals/Number tested. Number in parentheses indicates HI antibody titer.

f) NT: not tested.
} 
TABLE II

Susceptibility of guinea pigs to intranasal inoculation with measles virus

\begin{tabular}{llclc}
\hline \multirow{2}{*}{ Virus strain } & Age of animal & $\begin{array}{c}\text { Virus antigen } \\
\text { in lymphoid } \\
\text { tissues }\end{array}$ & \multicolumn{2}{c}{$\begin{array}{c}\text { Antibody response } \\
\text { (days pi) }\end{array}$} \\
\cline { 4 - 5 } & & & 14 & 33 \\
\hline Toyoshima & 11 days & $4 / 4^{b)}$ & $0 / 4$ & $3 / 3$ \\
& over 6 weeks & $2 / 2$ & $0 / 4$ & $3 / 3$ \\
\hline Leningrad-16 & 11 days & $5 / 6$ & $\mathrm{NT}^{c)}$ & $\mathrm{NT}$ \\
& 3 weeks & $5 / 6$ & $\mathrm{NT}$ & $\mathrm{NT}$ \\
\hline
\end{tabular}

a) The spleen and mesenteric lymph nodes were examined by the immunofluorescent technique 7 days pi.

b) Antigen-positive animals/Number tested.

c) NT: not tested.

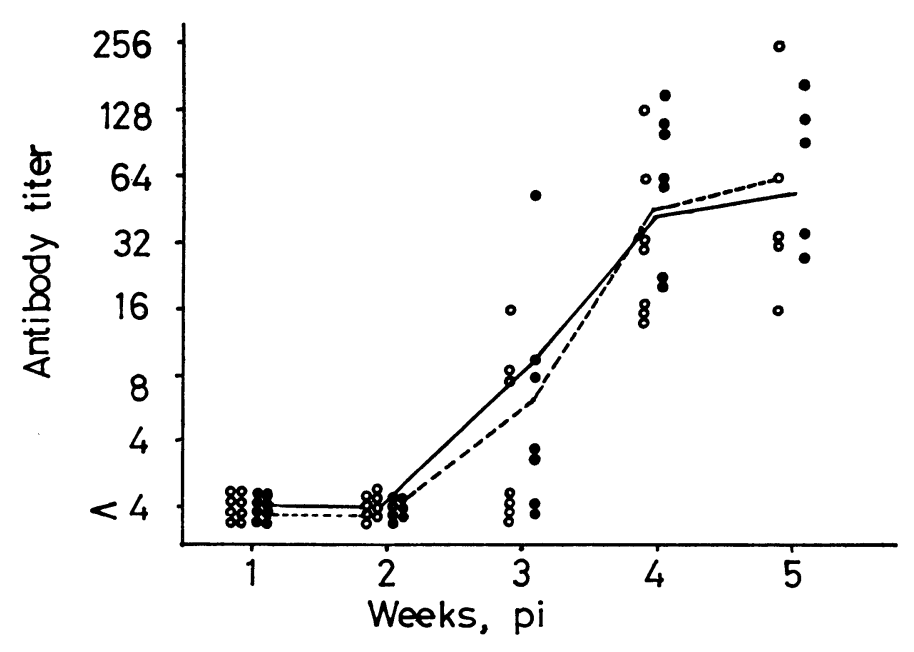

\section{$\circ \mathrm{HI}$ antibody $\bullet$ Virus neutralizing antibody}

Fig. 1. Antibody responses to measles virus. Guinea pigs were inoculated intranasally with Toyoshima strain of measles virus $\left(3.1 \times 10^{5} \mathrm{PFU} /\right.$ animal), and their sera were collected at weekly intervals for determination of $\mathrm{HI}$ and virus neutralizing antibodies.

In the following experiment, Toyoshima strain, which showed the highest antibody response, and Leningrad-16 strain, which had been adapted in guinea pig kidney cells, were examined by intranasal inoculation into guinea pigs at different ages. As shown in Table II, virus antigens were demonstrated in the spleen and mesenteric lymph nodes 7 days pi with both virus strains. Both HI and virus neutralizing antibodies were also developed although they tended to delay compared with the ip inoculation (Fig. 1). 
TABLE III

Skin reactions to measles virus antigen

\begin{tabular}{cclll}
\hline Weeks pi & \multicolumn{4}{c}{ Skin reaction $^{a)}$} \\
\hline 2 & $\left.7.0 / 7.0^{b}\right)$ & $16.5 / 4.5$ & $20.0 / 6.5$ & \\
\hline 3 & $0 / 0$ & $14.5 / 6.5$ & $20.0 / 0$ & \\
\hline 4 & $9.5 / 0$ & $11.0 / 0$ & $14.5 / 0$ & \\
\hline 5 & $9.0 / 0$ & $10.0 / 4.0$ & $10.0 / 0$ & $16.0 / 6.0$ \\
\hline
\end{tabular}

a) Diameters (mm) of skin erythema $24 \mathrm{hr}$ after intradermal inoculation.

b) Skin reaction to measles virus/skin reaction to control antigen.

From these results, the intranasal inoculation of Toyoshima strain was selected as a standard experimental condition in the subsequent experiments.

\section{Development of Cell-mediated Immunity to Measles Virus}

Thirteen guinea pigs were intranasally inoculated with Toyoshima strain, and three or four animals were examined by skin tests with both the measles virus antigen and control one 2, 3, 4, and 5 weeks pi. The results are shown in Table III. Moderate skin reaction to the control antigen was observed in some of the animals. Markedly higher skin reaction to the virus antigen than that to the control one was demonstrated in two of three animals 2 and 3 weeks pi, and in all the animals 4 and 5 weeks pi.

In a separate experiment, six guinea pigs were similarly inoculated with the virus and intraperitoneally with liquid paraffin 25 days pi. Skin tests were conducted 28 days pi and peritoneal exudate cells were collected after reading the skin reactions. All six animals showed positive skin reactions to the virus antigen. The migration of peritoneal exudate cells was inhibited by 32 to $88 \%$ with a mean value of $55 \%$ in the presence of virus antigen.

Thus, the intranasal inoculation with Toyoshima strain was suggested to induce virus-specific delayed hypersensitivity.

\section{Suppression of Skin Reaction to Tuberculin by Measles Virus Infection}

Effect of measles virus on the expression of delayed hypersensitivity to PPD was examined on guinea pigs immunized with tubercle bacilli 6 weeks earlier. Four groups of the immunized animals, each consisting of four animals, were intranasally or intraperitoneally inoculated with either Toyoshima or Leningrad16 strain, and skin tests were conducted at intervals after the virus inoculation. The results are summarized in Table IV. By the intranasal inoculation with Toyoshima or Leningrad-16 strain, marked decrease in the skin reactivities was induced in all the animals, 7 and 11 days pi, and Toyoshima strain-inoculated animals tended to recover to normal reactivity 33 days pi. 
TABLE IV

Effect of measles virus infection on skin reaction to tuberculin

\begin{tabular}{|c|c|c|c|c|c|c|c|}
\hline \multirow{2}{*}{$\begin{array}{l}\begin{array}{l}\text { Route of } \\
\text { inoculation }\end{array} \\
\text { Intranasal }\end{array}$} & \multirow{2}{*}{$\begin{array}{c}\text { Virus strain } \\
\text { Toyoshima }\end{array}$} & \multirow{2}{*}{$\begin{array}{c}\text { Days pi } \\
0\end{array}$} & \multicolumn{3}{|c|}{ Skin reaction } & \multirow{2}{*}{\multicolumn{2}{|c|}{$\begin{array}{l}\text { Mean } \\
16.6 \pm 1.1\end{array}$}} \\
\hline & & & $\left.17.0^{a}\right)$ & 16.5 & 17.9 & & \\
\hline & & 7 & $\begin{array}{l}9.0 \\
(47.0)^{0)}\end{array}$ & $\begin{array}{l}8.0 \\
(51.5)\end{array}$ & $\begin{array}{c}9.5 \\
(46.9)\end{array}$ & $\begin{array}{c}10.5 \\
(30.0)\end{array}$ & $\begin{array}{l}9.3 \pm 0.9^{* * c)} \\
(43.9)\end{array}$ \\
\hline & & 11 & $\begin{array}{c}9.0 \\
(47.0)\end{array}$ & $\begin{array}{c}9.5 \\
(48.5)\end{array}$ & $\begin{array}{l}10.5 \\
(41.3)\end{array}$ & $\begin{array}{l}7.0 \\
(53.3)\end{array}$ & $\begin{array}{l}9.0 \pm 1.3^{* *} \\
(47.5)\end{array}$ \\
\hline & & 33 & $\mathrm{NT}^{d)}$ & $\begin{array}{l}16.0 \\
(3.0)\end{array}$ & $\begin{array}{l}18.0 \\
(0)\end{array}$ & NT & $\begin{array}{l}17.0 \pm 1.0 \\
(1.5)\end{array}$ \\
\hline & Leningrad-16 & 0 & 14.5 & 14.6 & 17.0 & 14.5 & $15.2 \pm 1.1$ \\
\hline & & 7 & $\begin{array}{l}8.5 \\
(41.3)\end{array}$ & $\begin{array}{l}8.0 \\
(45.2)\end{array}$ & $\begin{array}{l}12.5 \\
(26.5)\end{array}$ & $\begin{array}{l}11.0 \\
(24.1)\end{array}$ & $\begin{array}{l}10.0 \pm 1.8 \\
(34.3)\end{array}$ \\
\hline & & 11 & $\begin{array}{l}9.5 \\
(34.5)\end{array}$ & $\begin{array}{l}7.0 \\
(52.1)\end{array}$ & $\begin{array}{l}6.5 \\
(61.8)\end{array}$ & $\begin{array}{l}10.5 \\
(27.6)\end{array}$ & $\begin{array}{l}8.4 \pm 1.7^{* c)} \\
(44.0)\end{array}$ \\
\hline \multirow[t]{6}{*}{ Intraperitoneal } & Toyoshima & 0 & 16.5 & 15.5 & 11.4 & 19.0 & $15.6 \pm 2.7$ \\
\hline & & 3 & $\begin{array}{l}12.0 \\
(27.3)\end{array}$ & $\begin{array}{l}16.5 \\
(6.5)\end{array}$ & $\begin{array}{l}11.0 \\
(3.5)\end{array}$ & $\begin{array}{l}15.9 \\
(16.3)\end{array}$ & $\begin{array}{l}13.9 \pm 2.4 \\
(10.2)\end{array}$ \\
\hline & & 7 & NT & $\begin{array}{c}8.0 \\
(45.1)\end{array}$ & $\begin{array}{l}11.5 \\
(0)\end{array}$ & $\begin{array}{l}14.5 \\
(23.7)\end{array}$ & $\begin{array}{l}11.3 \pm 2.7 \\
(22.9)\end{array}$ \\
\hline & Leningrad-16 & 0 & 16.1 & 14.0 & 14.5 & 16.9 & $15.4 \pm 1.2$ \\
\hline & & 3 & $\begin{array}{l}15.0 \\
(6.8)\end{array}$ & $\begin{array}{l}14.0 \\
(0)\end{array}$ & $\begin{array}{l}14.5 \\
(0)\end{array}$ & $\begin{array}{l}13.0 \\
(13.1)\end{array}$ & $\begin{array}{l}14.1 \pm 0.7 \\
(5.0)\end{array}$ \\
\hline & & 7 & $\begin{array}{l}15.5 \\
(3.7)\end{array}$ & $\begin{array}{c}15.5 \\
(-7.1)\end{array}$ & $\begin{array}{c}9.5 \\
(34.5)\end{array}$ & $\begin{array}{l}12.5 \\
(26.0)\end{array}$ & $\begin{array}{l}13.3 \pm 2.5 \\
(14.3)\end{array}$ \\
\hline
\end{tabular}

a) Diameter of skin reaction (diameters of erythema in $\mathrm{mm}$ ) for individual animal $24 \mathrm{hr}$ after intradermal inoculation.

c) $* \mathrm{p}<0.05 * * \mathrm{p}<0.01$.

b) \% inhibition of skin reaction to the value on day 0 .

d) NT: tested.

The ip inoculations decreased the skin reactivity in half of the animals 7 days pi for both virus strains, but the decrease was not so marked as that caused by the intranasal inoculation.

Effect of measles virus infection on the development of delayed hypersensitivity to PPD was examined by inoculating guinea pigs intranasally with Toyoshima strain on the day of immunization with tubercle bacilli or 3 days before the immunization. Three weeks after the immunization, skin tests were conducted. As shown in Table V, a marked suppression of the induction of skin reactivity was noticed in the animals inoculated with virus 3 days before the immunization, but not in those inoculated on the day of immunization.

These results indicate that the infection of guinea pigs with measles virus through the intranasal route causes the suppression of delayed hypersensitivity at both induction and expression phases. 
TABLE V

Effect of measles virus infection on development of delayed hypersensitivity to tuberculin

\begin{tabular}{lll}
\hline \multicolumn{1}{c}{ Group } & $\begin{array}{l}\text { Skin reaction } \\
\text { to PPD }\end{array}$ & Mean \\
\hline Immunized $^{(a)}$ but & $12.5 / 15.5^{c)}$ & \\
uninfected $^{15.0 / 20.9}$ & $18.2 \pm 4.6 / 22.9 \pm 5.1$ \\
& $22.5 / 26.0$ & \\
& $22.9 / 29.0$ & \\
\hline Infected on the day & $10.0 / 12.9$ & \\
of immunization & $12.9 / 15.0$ & $14.8 \pm 3.6 / 18.9 \pm 5.0$ \\
& $17.5 / 22.5$ & \\
& $18.9 / 25.0$ & \\
\hline Infected 3 days & $0 / 6.5$ & \\
before immunization & $6.0 / 13.4$ & $7.0 \pm 6.2 / 12.9 \pm 5.1$ \\
& $15.0 / 18.9$ & \\
\hline
\end{tabular}

a) A suspension of heat-inactivated tubercle bacilli in oil was intramuscularly inoculated.

b) The skin test was conducted with $0.07 \mu \mathrm{g}$ of PPD 3 weeks after immunization.

c) Diameters $(\mathrm{mm})$ of induration/diameters of erythema 24 $\mathrm{hr}$ after intradermal inoculation.

TABLE VI

Effect of measles virus infection on proliferative response of spleen cells to PPD

\begin{tabular}{|c|c|c|c|c|c|}
\hline \multirow{2}{*}{ Group } & & \multirow{2}{*}{$\begin{array}{l}\text { Animal } \\
\text { No. }\end{array}$} & \multicolumn{2}{|c|}{ Skin reaction $(\mathrm{mm})$} & \multirow{2}{*}{$\begin{array}{l}\text { Stimulation } \\
\text { index }\end{array}$} \\
\hline & & & Pre-inoculation & Post-inoculation & \\
\hline \multirow[t]{4}{*}{7 days pi } & Infected & 1 & 14.0 & 10.0 & 16.8 \\
\hline & & 2 & 14.5 & 13.0 & 16.7 \\
\hline & Uninfected & 3 & 13.0 & $\mathrm{NT}^{a}$ ) & 10.9 \\
\hline & & 4 & 12.0 & NT & 15.7 \\
\hline \multirow[t]{4}{*}{11 days pi } & Infected & 5 & 15.5 & 10.0 & 32.0 \\
\hline & & 6 & 13.0 & 4.0 & 25.6 \\
\hline & Uninfected & 7 & 14.0 & NT & 17.0 \\
\hline & & 8 & 13.0 & NT & 15.7 \\
\hline \multirow[t]{4}{*}{14 days pi } & Infected & 9 & 18.0 & 7.0 & 41.0 \\
\hline & & 10 & 18.0 & 10.0 & 33.1 \\
\hline & Uninfected & 11 & 18.0 & NT & 39.0 \\
\hline & & 12 & 16.0 & NT & 23.7 \\
\hline
\end{tabular}

a) NT: not tested. 
TABLE VII

Effect of measles virus infection on $S R F^{a)}$-induced skin reaction

\begin{tabular}{ccccc}
\hline \multirow{2}{*}{ Exp. } & Group & $\begin{array}{l}\text { Number of } \\
\text { animals }\end{array}$ & \multicolumn{2}{c}{ Skin reaction (mm) to } \\
\cline { 4 - 5 } & & & Undiluted SRF & $1: 3$ diluted SRF \\
\hline 1 & Uninfected & 7 & $15.3 \pm 1.5$ & $11.8 \pm 1.2$ \\
& 3 days pi & 4 & $13.8 \pm 2.8$ & $8.1 \pm 6.0$ \\
& 7 days pi & 4 & $13.0 \pm 1.9$ & $9.6 \pm 3.2$ \\
& 10 days pi & 4 & $13.0 \pm 1.7$ & $8.8 \pm 5.4$ \\
& 14 days pi & 4 & $14.7 \pm 1.1$ & $10.1 \pm 2.7$ \\
\hline 2 & Uninfected & 4 & $15.6 \pm 0.3$ & $13.1 \pm 1.3$ \\
& 7 days pi & 4 & $12.9 \pm 0.7 * b)$ & $9.4 \pm 0.6$ \\
& 10 days pi & 4 & $13.7 \pm 1.6$ & $11.3 \pm 2.0$ \\
& 14 days pi & 4 & $14.3 \pm 1.6$ & $11.8 \pm 1.6$ \\
\hline
\end{tabular}

a) SRF : Skin reacting factor; spleen cells of tuberculin-sensitized guinea pigs were cultured in the presence of $\mathrm{PPD}$, and the culture fluid was used as an SRF preparation.

b) $\mathrm{p}<0.05$.

\section{Effect of Measles Virus Infection on the Proliferative Response of Lymphocytes to PPD}

The three groups of guinea pigs immunized with tubercle bacilli, each consisting of two virus-inoculated animals and two uninfected controls, were examined for the in vitro proliferative response of the spleen cells to PPD in comparison with skin reaction to PPD 7, 11, and 14 days pi. As shown in Table VI, suppression of skin reactivity to PPD was noticed in virus-infected animals except guinea pig No. 2. Nevertheless, the spleen cells responded to the stimulus with PPD showing stimulation indices on similar or slightly higher levels compared with those in uninfected controls. Therefore, no impairment of PPD-specific $\mathrm{T}$ lymphocytes in the spleen was suggested in spite of the decreased skin reactivity.

\section{Effect of Measles Virus Infection on Skin Reactivity to SRF}

Since the in vitro responsiveness of spleen cells to PPD was shown to be on a normal level in the previous experiment, skin reactivity to SRF, which was considered to be a lymphokine(s) produced by PPD-specific $\mathrm{T}$ lymphocytes, (Bennett and Bloom, 1968) was examined.

To avoid possible sensitization with repeated inoculations with SRF, skin tests were made at the same time by the intradermal (id) inoculation of two different dilutions of the same lot of SRF preparation into the animals inoculated with virus $3,7,10,14$ days before, and to the uninfected controls as well. The results of two experiments are summarized in Table VII. The skin reactivity to SRF tended to decrease in virus-infected animals 3-10 day pi in 
TABLE VIII

Effect of measles virus infection on development of delayed hypersensitivity to OVA $A^{a)}$

\begin{tabular}{lccccccc}
\hline \multirow{2}{*}{ Group } & \multirow{2}{*}{$\begin{array}{c}\text { Animal } \\
\text { No. }\end{array}$} & \multicolumn{2}{c}{ Skin reaction to OVA at a dose of } & & \multicolumn{2}{c}{ Skin reaction to PPD } \\
\cline { 3 - 4 } \cline { 7 - 8 } & $10 \mu \mathrm{g}$ & $5 \mu \mathrm{g}$ & $1 \mu \mathrm{g}$ & & Pre-infection 8 days pi \\
\hline Uninfected & 1 & $\left.17.0^{b}\right)$ & 12.0 & 6.5 & & 18.0 & 17.0 \\
& 2 & 12.0 & 6.5 & 5.0 & & 17.0 & 16.5 \\
& 3 & 13.5 & 8.5 & 5.0 & & 17.0 & 17.0 \\
& 4 & 8.0 & 6.5 & 3.0 & & 18.0 & 17.0 \\
& 5 & 9.0 & 6.5 & 5.5 & & 18.0 & 17.0 \\
& $($ Mean $)$ & $(11.9 \pm 3.2)$ & $(8.0 \pm 2.1)$ & $(5.0 \pm 1.1)$ & & $(17.5 \pm 0.5)$ & $(17.1 \pm 0.5)$ \\
\hline Infected & 6 & 11.5 & 9.0 & 5.0 & & 18.0 & 14.0 \\
3 days & 7 & 13.5 & 10.0 & 8.0 & & 18.0 & 14.0 \\
before OVA & 8 & 8.0 & 7.0 & 3.0 & & 16.0 & 14.5 \\
immunization & 9 & 7.0 & 6.5 & 4.0 & & 16.0 & 10.0 \\
& 10 & 12.0 & 7.0 & 5.5 & & 16.0 & 16.0 \\
& $($ Mean) & $(10.4 \pm 2.5)$ & $(7.9 \pm 1.4)$ & $(5.1 \pm 1.7)$ & & $(16.8 \pm 1.0)$ & $(13.7 \pm 2.0)$ \\
\hline
\end{tabular}

a) Tuberculin-sensitized guinea pigs, either uninfected or infected with measles virus 3 days before, were each immunized with $50 \mu \mathrm{g}$ of ovalbumin (OVA). Five days later (8 days after virus infection), the animals were examined for skin reactivities to both OVA and PPD.

b) Diameters of erythema in $\mathrm{mm} 24 \mathrm{hr}$ after intradermal inoculation.

both experiments, statistically significant suppression being noticed 7 days pi in Exp. 2.

\section{Effect of Measles Virus Infection on Development of Skin Reaction to $O V A$}

Since the suppressive effect of measles virus on tuberculin-type delayed hypersensitivity was confirmed in the previous experiments, effect of the virus on Jones-Mote-type hypersensitivity, another form of delayed skin reaction (Richerson, Dvorak and Leskowitz, 1969), was examined. Two groups of five animals previously immunized with tubercle bacilli were immunized with OVA, the one group being infected with virus 3 days before and the other one being left as uninfected controls. Five days after the immunization with OVA, the animals were examined for skin reactivities to PPD and OVA. In the virusinfected animals, significant suppression of skin reactivity to PPD was observed in three of the five animals, whereas skin reactivity to OVA at three different doses were demonstrated to be on similar levels to those in uninfected controls (Table VIII). The results suggest that the virus exerts suppressive effect on hypersensitivity of tuberculin-type but not on that of Jones-Mote type. 
TABLE IX

Effect of measles virus infection on skin reaction to $\mathrm{PHA}$

\begin{tabular}{|c|c|c|c|}
\hline \multirow{2}{*}{ Group $^{a)}$} & \multicolumn{3}{|c|}{ Skin reaction to PHA at a dose of } \\
\hline & $20 \mu \mathrm{g}$ & $10 \mu \mathrm{g}$ & $5 \mu \mathrm{g}$ \\
\hline Uninfected & $11.9 \pm 0.7^{b)}$ & $9.8 \pm 0.7$ & $7.5 \pm 0.6$ \\
\hline 4 days $\mathrm{pi}$ & $15.5 \pm 1.0^{*(c)}$ & $12.5 \pm 0.8$ & $10.5 \pm 0.8^{*}$ \\
\hline 7 days $\mathrm{pi}$ & $12.7 \pm 0.6$ & $11.4 \pm 0.7$ & $8.5 \pm 0.8$ \\
\hline 10 days $\mathrm{pi}$ & $12.0 \pm 1.0$ & $10.5 \pm 0.9$ & $8.4 \pm 1.7$ \\
\hline 14 days $\mathrm{pi}$ & $11.8 \pm 1.0$ & $9.6 \pm 1.5$ & $7.6 \pm 2.2$ \\
\hline
\end{tabular}

a) Each group consists of 4 animals.

b) Mean of skin reactions (diameters of erythema in $\mathrm{mm}) 6.5 \mathrm{hr}$ after intradermal inoculation.

c) $\mathrm{p}<0.05$.

\section{Effect of Measles Virus Infection on Skin Reaction to Phytohemagglutinin $(P H A)$}

Skin reactivity to $\mathrm{PHA}$, which has been applied for the clinical evaluation of cell-mediated immunity (Bonforte et al., 1972; Schrek and Stefani, 1963), was investigated on measles virus-infected guinea pigs by id inoculations with different doses of PHA. As repeated inoculations with PHA were found to cause enhanced skin reactions to PHA in preliminary tests, the animals received single inoculations with PHA 4, 7, 10, or 14 days pi. The results of a typical experiment are shown in Table IX. Skin reactivity to PHA increased transiently 4 days pi, and returned to a normal level 7 or 10 days pi. This tendency of transient enhancement 4 days pi was confirmed in repeated experiments.

In a separate experiment, spleen cells were obtained from the animals at similar intervals after virus inoculation and examined for in vitro proliferative response to PHA. In contrast to enhanced skin reactivity to PHA, no significant change in in vitro response was observed (data not shown).

\section{Discussion}

Suppression of delayed hypersensitivity by measles virus has been paid special attention since the finding by von Pirquet (1908) of tuberculin anergy. However, no experimental model has been available except a murine model (McFarland, 1974) for the virus-induced suppression of antibody response. In the present study, a guinea-pig model was proven to be useful for the suppression of delayed hypersensitivity by measles virus as well as for the development of virus-specific delayed hypersensitivity. The intranasal inoculation with Toyoshima strain was shown to cause successful infection of guinea pigs as indicated by the virus growth in the lymphoid tissues and the development of both humoral and cell-mediated immunities to measles virus. Although the reason for the failure in virus growth by the ip route of inoculation remains to be 
clarified, this result seems to be compatible with the finding by Numazaki and Karzon (1966) who demonstrated antibody responses to both soluble internal viral antigen and viral envelope antigen in guinea pigs by the intranasal inoculation.

Significant suppression of skin reaction to tuberculin was demonstrated in the animals inoculated intranasally with measles virus at both induction and expression phases, but not in those inoculated intraperitoneally. Since virus growth was observed after the intranasal inoculation but not after the ip inoculation, the virus growth in the lymphoid tissues is suggested to be involved in the immunosuppression.

It is interesting that the induction of Jones-Mote-type hypersensitivity to OVA was not suppressed in spite of the suppression of tuberculin-type delayed hypersensitivity. Since participation of different populations of lymphoid cells in these two types of delayed hypersensitivity reactions was suggested (Richerson et al., 1969), measles virus might affect the effector cells involved in tuberculintype but not those involved in Jones-Mote-type reaction.

As to the mechanisms of measles virus-induced immunosuppression in humans, the following possibilities have been speculated: (1) direct suppression of the lymphocyte function by infectious virus (Sullivan et al., 1975), (2) a suppressive factor of low molecular weight in the measles virion (Zweiman, 1972), (3) suppression of the macrophage function (Finkel and Dent, 1973), and (4) shortage of $T$-cell pool caused by a recruitment of $T$ cells to the site of virus growth (Burnet, 1968).

The general course of measles virus infection in guinea pigs is much milder without any clinical sign than that of human measles. Histological lesions such as giant cells and lymphoid necrosis which are indicative of viral cytopathic effect on lymphoid cells are not detected (White and Boyd, 1973; Yamanouchi et al., 1973). Moreover, in vitro secondary response of spleen cells to PPD was not impaired by measles virus infection. Therefore, the virus may not exhibit any suppressive effect on the lymphocyte functions. On the other hand, the response to SRF, lymphokine(s) mediating skin reaction (Bennett and Bloom, 1968), was suppressed. These results may suggest that measles virus affects the stage of cellular infiltration to the skin reaction site. Impairment of the macrophage function is compatible with this hypothesis.

As an alternative, activation of suppressor cells by measles virus infection may be speculated. Thus far, such activation of suppressor cells was reported only for chickens infected with Marek's disease virus in which suppressor macrophages were shown to inhibit lymphocyte blastogenesis (Lee et al., 1978). This possibility remains to be examined in the present model.

The immunosuppressive effect of measles virus in guinea pigs in the present study is relatively mild, thus the suppression of delayed skin reaction to tuberculosis is not always demonstrated in all the virus-inoculated animals. Such mild immunosuppressive effect of a similar degree was reported also for humans after the administration of live measles vaccine (Fireman et al., 1969). 
To analyze the immunosuppression mechanism in detail, use of more virulent virus which can exert more marked suppressive effect as observed in humans during natural measles seems to be essential. Adaptation of measles virus in guinea pigs for this purpose is now in progress.

Besides the suppressive effect on delayed hypersensitivity, measles virus infection was indicated to cause a transient enhancement of PHA skin reaction in guinea pigs. In contrast, suppression of PHA skin reaction was reported in natural measles in humans (Saeki et al., 1973). However, the response at such an early stage as 4 days after infection when the enhancement was noticed in the present study was not investigated in humans.

Although the significance of these alterations of host's immune functions during measles virus infection is unknown at the moment, intricate interactions between infection with lymphoproliferative virus and the immune system are suggested.

\section{REFERENCES}

Bech, V. (1962): Measles epidemics in Greenland. Amer. J. Dis. Child., 103, 252-253.

Bennett, B. AND Bloom, B. R. (1968): Reactions in vivo and in vitro produced by a soluble substance associated with delayed-type hypersensitivity. Proc. Natl. Acad. Sci., 59, 756-762.

Blumberg, R. W. and Cassady, H. A. (1947): Effect of measles on the nephrotic syndrome. Amer. J. Dis. Child., 73, 151-166.

Blumhardt, R., Pappano, J. E., Jr. and Moyer, D. G. (1968): Depression of poison ivy skin tests by measles vaccine. J. Amer. Med. Assoc., 206, 2739-2741.

Bonforte, R. J., Topilsky, M., Siltzbach, L. E. ANd Glade, P. R. (1972): Phytohemagglutinin skin test: A possible in vivo measure of cell-mediated immunity. J. Pediat., 81, 775-780.

Brody, J. A., Overfield, T. ANd Hammes, L. M. (1964): Depression of the tuberculin reaction by viral vaccines. New Engl. J. Med., 271, 1294-1296.

Burnet, F. M. (1968): Measles as an index of immunological function. Lancet, ii, 610-613.

Coovadia, H. M., Wesley, A., Henderson, L. G., Brain, P., Vos, G. H. and Halett, A. F. (1978): Alterations in immune responsiveness in acute measles and chronic post-measles chest disease. Int. Arch. Allergy Appl. Immunol., 56, 14-23.

Finkel, A. AND Dent, P. B. (1973): Abnormalities in lymphocyte proliferation in classical and atypical measles infection. Cell. Immunol., 6, 41-48.

Fireman, P., Friday, G. And Kumate, J. (1969): Effect of measles vaccine on immunologic responsiveness. Pediatrics, 43, 264-272.

Lee, L. F., Sharma, J. M., Nazerian, K. and Witter, R. L. (1978): Suppression of mitogeninduced proliferation of normal spleen cells by macrophages from chickens inoculated with Marek's disease virus. J. Immunol., 120, 1554-1559.

MaFarland, H. F. (1974): The effect of measles virus infection on $\mathbf{T}$ and $\mathbf{B}$ lymphocytes in the mouse. 1. Suppression of helper cell activity. J. Immunol., 113, 1978-1983.

Mellman, W. J. and Wetton, R. (1963): Depression of the tuberculin reaction by attenuated measles virus vaccine. J. Lab. Clin. Med., 61, 453-458.

Morgan, E. M. AND RAPP, F. (1977): Measles virus and its associated diseases. Bacteriol. Rev., $41,636-666$.

Munyer, T. P., Mangi, R. J., Dolan, T. and Kantor, F. S. (1975): Depressed lymphocyte function after measles-rubella vaccination. J. Infect. Dis., 132, 75-78.

Numazaki, Y. AND Karzon, D. T. (1966): Soluble antigen of measles virus. J. Immunol., 97, $470-476$.

Richerson, H. B., Dvorak, H. F. ANd Leskowitz, S. (1969): Cutaneous basophil hypersensitivity. 1. A new look at the Jones-Mote reaction, general characteristics. J. Exptl. Med., 132, 546557. 
Saekr, Y., Nakayama, K., Nagamatsu, K., Togashi, T. and Matsumoto, S. (1973): Measles and PHA skin reaction. Igaku no Ayumi, 87, 313-314 (in Japanese).

Sato, H., Albrecht, P., Reynolds, D. W., Stagno, S. and Ennis, F. A. (1978): Transfer of measles, mumps, and rubella antibodies from mother to infant. Its effect on measles, mumps, and rubella immunization. Amer. J. Dis. Child., 133, 1240-1243.

Schrek, R. AND Stefani, S. S. (1963): Lymphocytic and intradermal reactions to phytohemagglutinin. Fed. Proc., 22, 428.

SchwATz, A. J. F. (1964): Immunization against measles. Developments and evaluation of a highly attenuated live measles vaccine. Ann. Pediat., 202, 241-252.

Smorodintsev, A. A., Boychuk, L. M., Shikina, E. S., Meshalova, V. N., Taros, L. Y., Aminova, M. G., Revenok, N. D. And Safarov, D. I. (1965): Prevention of measles by use of live vaccines in the USSR. Arch. Gesamte Virusforsch., 16, 284-293.

Sullivan, J. L., Barry, D. W., Albrecht, P. ANd Lucas, S. J. (1975): Inhibition of lymphocyte stimulation by measles virus. J. Immunol., 114, 1458-1461.

von Pirquet, C. E. (1908): Das Verhalten der Kutanen Tuberkulin-reaktion wahrend der Masern. Deut. Med. Wochensch., 34, 1297-1300.

Watanuki, M., Yoshida, T. and Hashimoto, T. (1969): Delayed hypersensitivity in vitro. 4. Production of macrophage migration inhibition factor by cells of tuberculin sensitive animals cultivated in vitro with antigen. Medicine and Biology, 79, 67-73 (in Japanese).

Wesley, A., Coovadia, H. M. ANd Henderson, L. (1978): Immunological recovery after measles. Clin. Exptl. Immunol., 32, 540-544.

White, R. G. ANd Boyd, J. F. (1973): The effect of measles on the thymus and other lymphoid tissues. Clin. Exptl. Immunol., 13, 343-357.

Yamanouchi, K., Fukuda, A., Kobune, F., Hayami, M. and Shishido, A. (1969): Serologic response in monkeys inoculated with rinderpest and measles viruses. Amer. J. Vet. Res., 30, 1831-1835.

Yamanouchi, K., Chino, F., Kobune, F., Kodama, H. and Tsuruhara, T. (1973): Growth of measles virus in the lymphoid tissues of monkeys. J. Infect. Dis., 128, 795-799.

Yamanouchi, K. (1980): Comparative aspects of pathogenicity of measles, canine distemper, and rinderpest viruses. Japan. J. Med. Sci. Biol., 33, 41-66.

Zweiman, B. (1972): Effect of viable and non-viable measles virus on proliferating human lymphocytes. Int. Arch. Allergy Appl. Immunol., 43, 600-607.

Zweiman, B., Pappagianis, D., Maibach, H. And Hilderth, E. A. (1971): Effect of measles immunization on tuberculin hypersensitivity and in vitro lymphocyte reactivity. Int. Arch. Allergy Appl. Immunol., 40, 834-841. 